Jurnal Inkofar * Volume 1 No. 2, Desember 2017 * ISSN: 2615-3645 (Print) / 2581-2920 (Online)

Tersedia secara online di: http://www.politeknikmeta.ac.id/meta/ojs/

\title{
SISTEM INFORMASI PERPUSTAKAAN BEBASIS WEB PADA SMK NEGERI 2 KOTA BEKASI
}

\author{
Dwi Ari Wibowo ${ }^{1}$, Verry Riyanto ${ }^{2}$, Syifa Nur Rakhmah ${ }^{3}$ \\ ${ }^{1}$ Manajemen Informatika; AMIK BSI Bekasi; Jl. Cut Mutiah No 88 Bekasi, 82425638; e-mail: \\ dwiari051@gmail.com \\ ${ }^{2}$ Teknik Informatika; STMIK Nusa Mandiri Jakarta; Jl. Damai No. 8 Warung Jati Barat \\ (Margasatwa), Jakarta Selatan, 8005722; e-mail:verry.vry@nusamandiri.ac.id \\ ${ }^{3}$ Sistem Informasi; STMIK Nusa Mandiri Jakarta; Jl. Damai No. 8 Warung Jati Barat (Margasatwa), \\ Jakarta Selatan, 8005722; e-mail: syifa.snk@nusamandiri.ac.id
}

\begin{abstract}
Technological developments are getting more recent, as well as developments in library empowerment today. The library provides a wide collection of books - information books to read, ranging from textbooks, story books, magazines and others. All collections of these books can be read in the library or borrowed for a certain period of time. In general, the library only has books that are stored on the shelves of the building or library space but in the current technological developments utilize the library debgan archiving collection of books in the form of digital archives or better known as e-books. Currently within the scope of education, digital libraries are needed to support the implementation of education and teaching, as well as community service and service in the form of facilitated services with online systems. The paradigm shift in the education and teaching system puts the library as a very important information resource because it is possible to provide convenience to the academic community in the accessibility of information in the library. In today's global era, various libraries are implementing information technology (IT), so the term virtual library, electronic library, or digital library.
\end{abstract}

Keywords: E-Library, Website, information system

\begin{abstract}
ABSTRAK
Perkembangan teknologi semakin hari semakin mutakhir, begitu pun dengan perkembangan dalam pemberdayaan perpustakaan saat ini. Perpustakaan menyediakan berbagai macam koleksi buku-buku informasi untuk dibaca, mulai dari buku pelajaran, buku cerita, majalah dan lain-lain. Semua koleksi buku-buku tersebut bisa dibaca di dalam perpustakaan ataupun dipinjam dengan jangka waktu tertentu. Pada umumnya perpustakaan hanya memiliki buku-buku yang disimpan di rak dari gedung atau ruang perpustakaan tetapi dalam perkembangan teknologi saat ini memanfaatkan perpustakaan debgan melakukan pengarsipan koleksi buku-buku dalam bentuk arsip digital atau yang lebih dikenal dengan e-book. Saat ini di dalam ruang lingkup pendidikan, perpustakaan digital diperlukan untuk mendukung dalam pelaksanaan pendidikan dan pengajaran, serta pengabdian dan pelayanan pada masyarakat dalam bentuk layanan yang dipermudah dengan sistem online. Perubahan paradigma dalam sistem pendidikan dan pengajaran menempatkan perpustakaan sebagai sumberdaya informasi yang sangat penting karena dimungkinkan akan memberikan kemudahan pada civitas akademika dalam aksesibilitas informasi di perpustakaan. Dalam era global seperti sekarang ini muncul berbagai perpustakaan yang menerapkan teknologi informasi (TI) maka adapun istilah perpustakaan maya, perpustakaan elektronik, atau perpustakaan digital.
\end{abstract}

Kata Kunci: Perpustakaan Digital, website, sistem informasi

\section{PENDAHULUAN}

Saat ini di lingkungan pendidikan, perpustakaan digital diperlukan untuk mendukung pelaksanaan pendidikan dan pengajaran, serta pengabdian dan pelayanan pada masyarakat. Perubahan paradigma dalam sistem pendidikan dan pengajaran menempatkan perpustakaan sebagai sumberdaya informasi yang sangat penting karena dimungkinkan akan memberikan kemudahan pada civitas akademika dalam aksesibilitas informasi di perpustakaan. Dalam era global seperti sekarang ini muncul berbagai perpustakaan yang menerapkan teknologi informasi maka adapun istilah perpustakaan maya, 
perpustakaan elektronik, perpustakaan digital dan sebagainya. Namun harus diingat bahwa pengalaman menunjukkan bahwa sebagian besar perpustakaan di Indonesia tepatnya di dunia pendidikan khususnya di SMK belum memiliki kemampuan untuk mengaplikasikan TI sehingga harus ada strategi khusus untuk mengembangkan sebuah perpustakaan dari bentuk konvensional ke bentuk digital. Kendala yang terjadi adalah perlunya biaya yang tidak sedikit karena untuk mendigitalkan sebuah dokumen dari bentuk cetak ke bentuk digital diperlukan beberapa tahap yaitu proses scanning, editing, perlindungan atau keamanan, jaringan intranet serta memerlukan pula komputer yang mempunyai performa atau kapasitas yang cukup tinggi.

Namun untuk jangka panjang, hal ini sangat menguntungkan bagi perpustakaan dan pengguna. Dalam berbagai kasus, penggunaan portal dalam berbagai perusahaan ternyata dapat memberikan penghematan luar biasa. Penggunaan teknologi informasi telah memberikan kemudahan dan penghematan kepada penggunanya. Termasuk penghematan biaya perawatan koleksi. Pengembangan perpustakaan digital atau e-library bagi tenaga pengelola perpustakaan dapat membantu pekerjaan di perpustakaan melalui fungsi sistem otomasi perpustakaan, sehingga proses pengelolaan perpustakaan lebih efektif dan efisien. Fungsi sistem otomasi perpustakaan menitikberatkan pada bagaimana mengontrol sistem administrasi layanan secara otomatis/terkomputerisasi. Sedangkan bagi pengguna perpustakaan dapat membantu mencari sumber-sumber informasi yang diinginkan dengan menggunakan catalog on-line yang dapat diakses melalui intranet maupun internet, sehingga pencarian informasi dapat dilakukan kapan pun dan di mana pun ia berada.

Pada perpustakaan SMK Negeri 2 Kota Bekasi masih menggunakan konsep perpustakaan konvensional dan jauh lebih lampau dalam fasilitas dari sistem yang digunakan pada perpustakaan digital. Para pengguna masih mencari buku dengan mencarinya satu persatu buku yang ada di perpustakaan atau mencarinya dari rak yang satu ke yang lain. Bahkan tidak sekali buku yang dicari tidak ditemukan sehingga ini sangat merepotkan bagi pengguna dan petugas perpustakaan. Tidak hanya pengguna saja yang mendapat kendala ternyata petugas juga kesulitan dalam pengolahan data terkait dengan informasi peminjaman, pengembalian, data buku serta pengelompokan buku sesuai dengan kategori buku. Sehingga menyulitkan petugas perpustakaan saat menyediakan laporan peminjaman, laporan pengembalian serta menyulitkan petugas untuk mencari buku yang diinginkan oleh pengguna karna mapping buku yang masih kurang jelas.

Dengan adanya sistem informasi perpustakaan yang penulis buat ini diharapkan dapat memperbaiki dan membuat pekerjaan menjadi lebih cepat sehingga tidak terjadi hambatan dan kendala dalam pencarian buku, peminjaman buku, pengembalian buku, jumlah stok yang ada di rak buku, laporan peminjaman buku dalam sebulan dan sebagainya. Adanya sistem informasi ini pun diharapkan dapat melihat seberapa besar minat membaca buku bagi siswa-siswi SMKN 2 Kota Bekasi. Sehingga sistem informasi perpustakaan ini memberikan kemudahan bagi masyarakat SMKN 2 Kota Bekasi baik siswa, guru, tata usaha, kepala sekolah, dan lain-lain. Serta perlahan akan tersingkir anggapan bahwa perpustakaan tidak tersentuh oleh IT.

\section{METODE PENELITIAN}

\subsection{Metode Pengembangan Perangkat Lunak}

Pendekatan yang kami lakukan dalam membangun suatu sistem informasi perpustakaan ini menggunakan metode Waterfall [Shalahuddin, 2014] dimana tahapan pengembangannya dimulai dari:

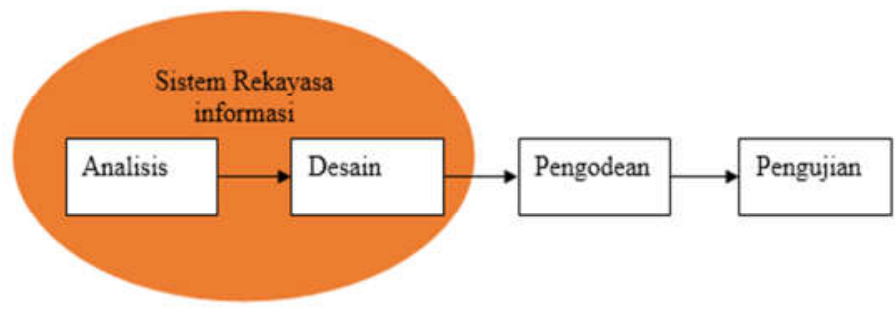

Gambar 1. Ilustrasi Model Waterfall

Sumber: Sukamto dan Shalahuddin . M (2014) 
1. Analisis kebutuhan perangkat lunak

Pada tahapan ini penulis mengumpulkan kebutuhan secara intensif dengan cara meninjau langsung dengan melihat berbagi referensi - referensi sistem informasi perpustakaan yang telah ada untuk menspesifikasikan kebutuhan perangkat lunak yang di butuhkan oleh petugas ataupun siswa dalam kata lain user agar dapat digunakan dengan baik.

2. Desain

Pada tahapan desain penulis menfokuskan pada empat atribut, yaitu struktur data, representasi antarmuka, arsitektur perangkat lunak, dan prosedur pengodean. Maka pada tahapa ini penulis menyediakan beberapa desain web yang responsif dengan tujuan dapat dibuka dari berbagai device baik yang memiliki layar besar ataupun kecil. Serta membuat desain yang memudahkan user saat menggunakan sistem informasi tersebut.

3. Pembuatan kode program

Setelah melewati tahapan desain selanjutnya penulis membuat kode program dengan mengacu pada desain sehingga terciptalah kesesuaian antara desain dengan kode program. Hasil dari tahapan ini adalah program komputer sesuai dengan desain yang telah dibuat pada tahapan desain.

4. Pengujian

Selanjutnya di tahapan penguji ini penulis memastikan bahwasannya semua bagian dari sistem secara mendetail untuk meminimalisir segala bentuk kesalahan (error) pada sistem serta memastikan hasil akhir berupa output dari sistem sesuai dengan yang diharapkan.

5. $\quad$ Pendukung (support) atau pemeliharaan (maintenance)

Dengan adanya tahapan ini penulis dapat mengetahui segala kesalahan yang tidak terdeteksi saat tahapan pengujian, sehingga pada tahapan pendukung atau pemeliharaan ini diizinkan untuk mengulangi proses dari tahapan - tahapan sebelumnya namun tidak membuat sistem yang baru.

\subsection{Teknik pengumpulan Data}

Teknik pengumpulan data yang digunakan oleh penulis dalam melakukan pengumpulan data untuk pembuatan penelitian ini adalah:

1. Pengamatan (Observasi)

Penulis melakukan pengamatan secara langsung terhadap kegiatan yang ada diperpustakaan SMKN 2 Kota Bekasi baik saat siswa meminjaman buku, mencarian buku, dan mengembalian buku. Serta mengamati proses transaksi yang dilakukan petugas perpustakaan saat proses peminjaman buku, pengembalian buku dan berbagai pemeliharaan data-data yang ada diperpustakaan. Hasil dari pengamatan tersebut langsung dicatat oleh penulis dan dari kegiatan observasi dapat diketahui bagaimana sistem informasi perpustakaan akan dibuat.

2. Wawancara (Interview)

Pada metode ini penulis memperoleh informasi dengan melakukan tanya jawab kepada siswa yang berada di perpustakaan mengenai beberapa hal seperti pencarian buku yang diinginkan, proses peminjaman dan pengembalian buku. Kemudian melakukan tanya jawab kepada Dewi sebagai petugas perpustakaan mengenai bagaimana proses administrasi-administrasi yang terjadi di perpustakaan seperti data jumlah buku, data buku yang ada diperpustakaan itu, data peminjam dan pengembalian buku.

3. Studi Pustaka

Penulis melakukan metode ini untuk memenuhi informasi bagaimana sistem informasi perpustakaan yang berkonsep IT dibuat, sehingga berusaha mendapatkan data dengan cara melihat, membaca, serta mengembangkan informasi yang berkaitan dengan masalah yang dibicarakan sebagai referensi dari berbagai buku cetak, ebook, maupun website E-library yang telah dibuat untuk penunjang penelitian ini.

\section{HASIL DAN PEMBAHASAN}

Perancangan perangkat lunak ini difokuskan pada tiga atribut, yaitu representasi rancangan antar muka, rancangan basis data hingga struktur navigasi. 


\subsection{Rancangan Antar Muka}

Dalam tahap ini penulis akan menjelaskan tentang perancangan antarmuka halaman aplikasi sistem informasi perpustakaan berbasis web pada SMKN 2 Kota Bekasi.

3.1.1 Rancangan Antar Muka Halaman Login Admin

Dalam halaman ini admin harus melakukan login terlebih dahulu untuk dapat mengakses sistem, dengan memasukkan username dan password admin langsung dapat mengakses sistem. Rancangan halaman login dapat dilihat pada Gambar 2

\section{SIMPUS}

Please login with your Username and Password.

$$
\text { Username }
$$

Password

\section{Login}

\section{Gambar 2. Rancangan Antar Muka Halaman Login Admin}

Sumber: : Hasil Penelitian (2017)

3.1.2 Rancangan Antar Muka Halaman Beranda Admin

Pada halaman ini menunjukkan bahwa admin telah login ke dalam sistem informasi perpustakaan, username dan password pengguna telah sesuai.

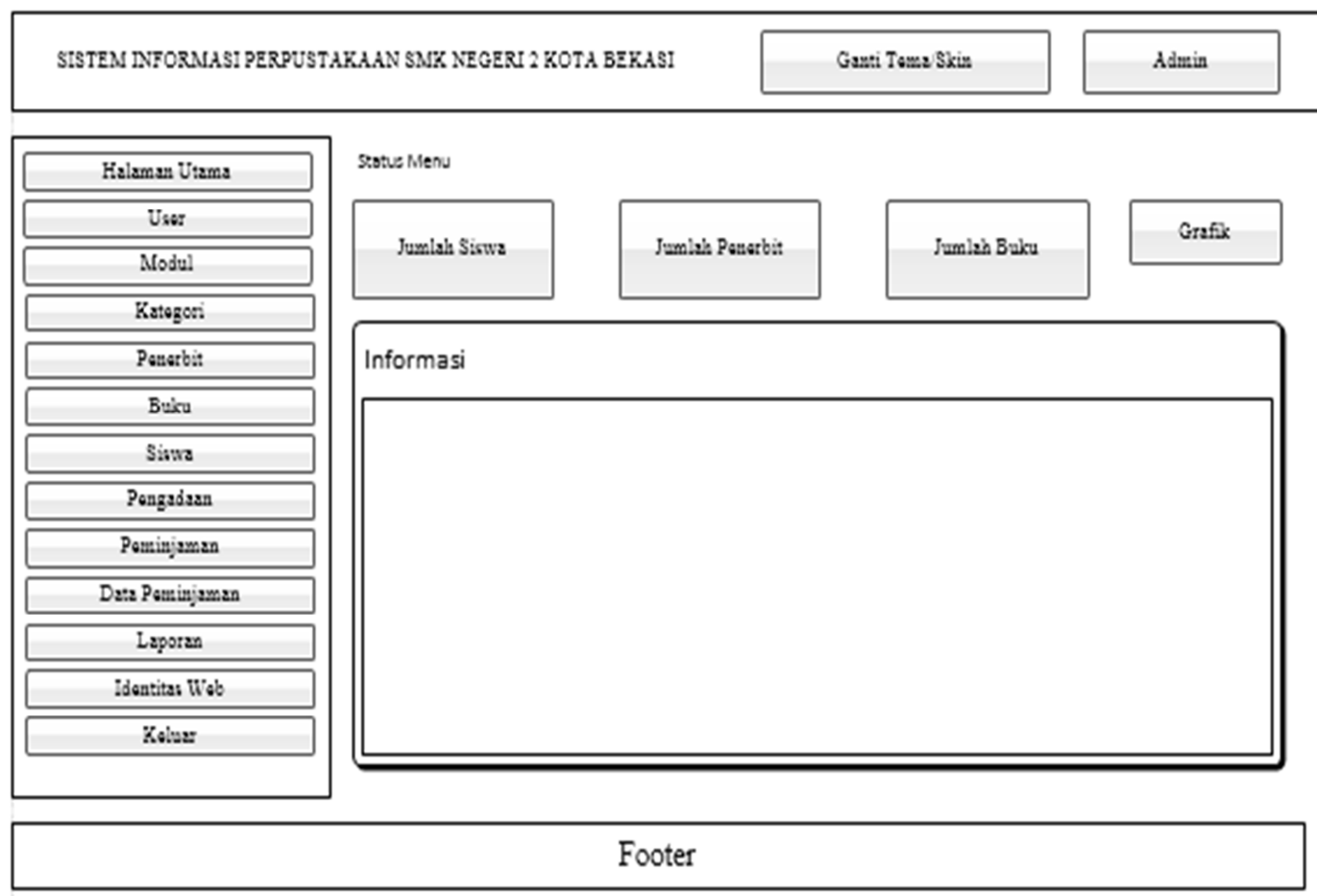

Gambar 3. Rancangan Antar Muka Halaman Utama Admin

Sumber: : Hasil Penelitian (2017) 


\subsection{Rancangan Basis Data}

3.2.1 Entity Relationship Diagram

Perancangan basis data menghasilkan pemetaan tabel-tabel yang digambarkan menggunakan Entity Relationship Diagram (ERD).

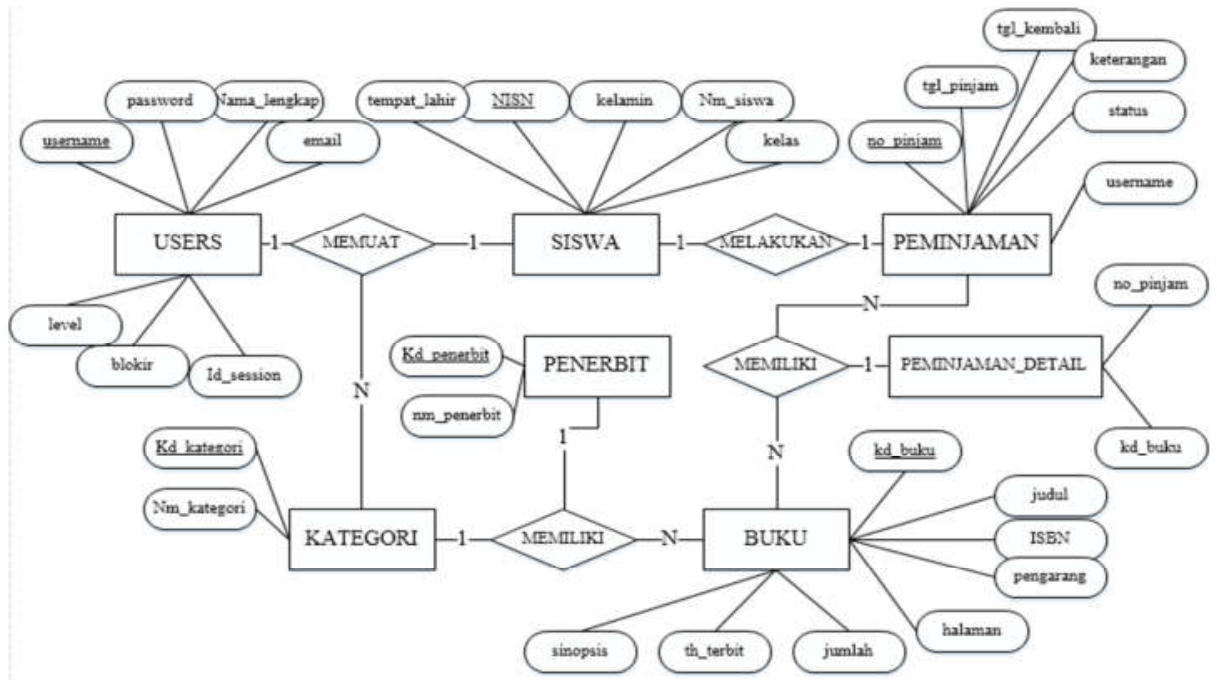

Gambar 4. Entity Relationship Diagram

Sumber: Hasil Penelitian (2017)

3.2.2 Logical Relational Structure (LRS)

Perancangan basis data menghasilkan pemetaan tabel-tabel dan atribut-atribut serta adanya relasi antar entitas yang digambarkan menggunakan Logical Relationship Diagram (LRS).

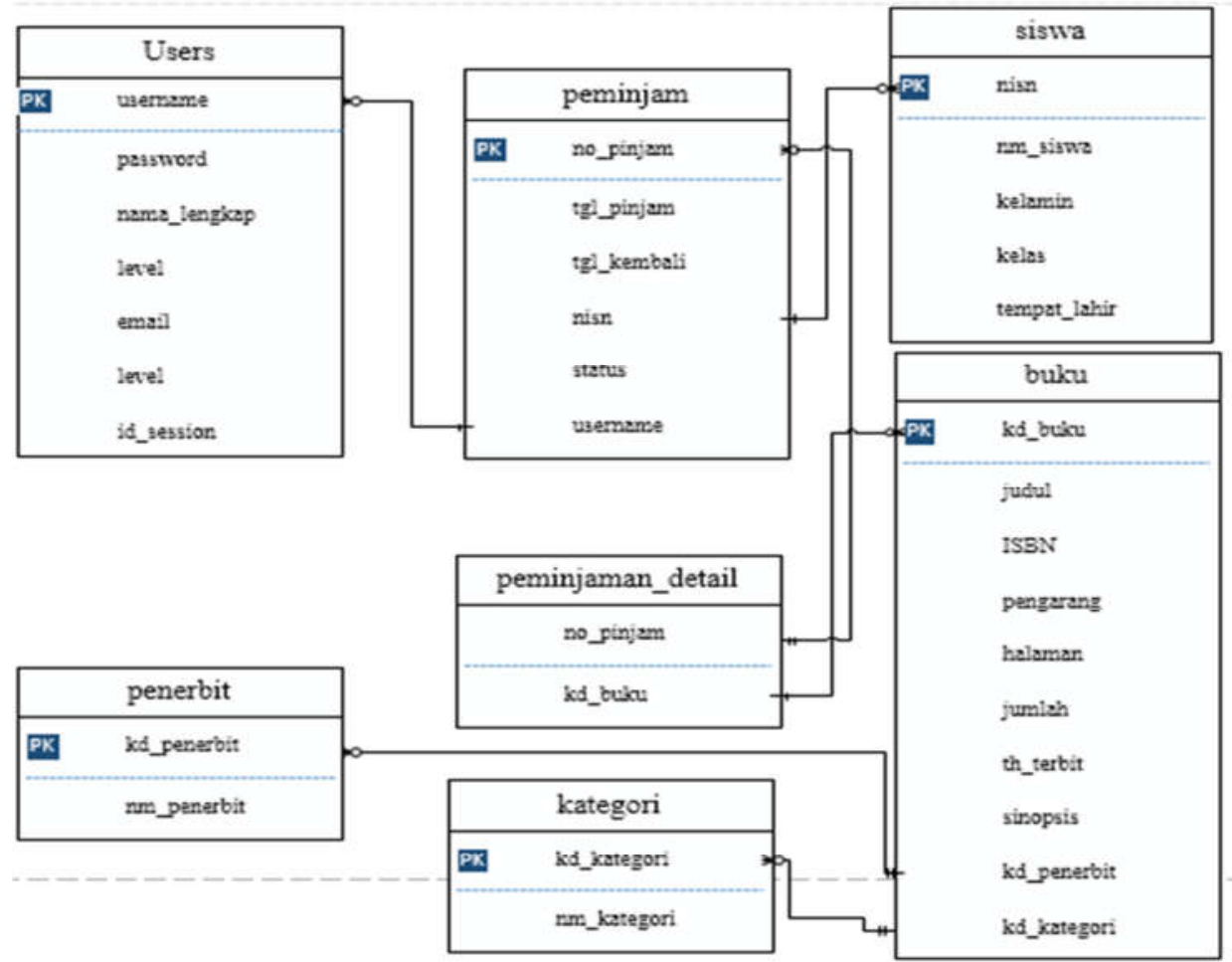

Gambar 5. Logical Relational Structure

Sumber: : Hasil Penelitian (2017) 


\subsection{Rancangan Struktur Navigasi}

Adapun struktur navigasi dari peracangan sistem informasi Perpustakaan berbasis web pada SMKN 2 Kota Bekasi ini menggunakan struktur navigasi komposit.

3.3.1 Struktur Navigasi Halaman Beranda Admin

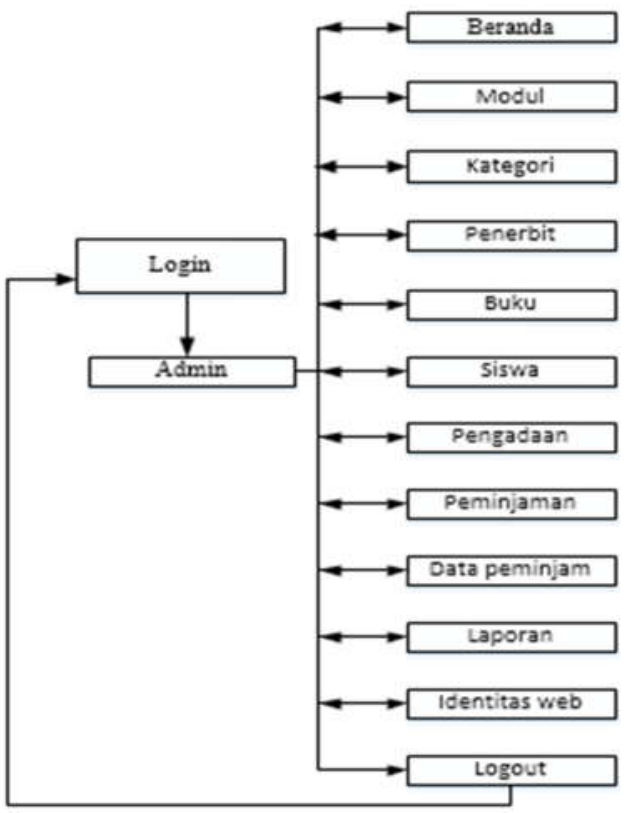

\section{Gambar 6. Struktur Navigasi Halaman Beranda Admin} Sumber: : Hasil Penelitian (2017)

\subsubsection{Struktur Navigasi Halaman Beranda User}

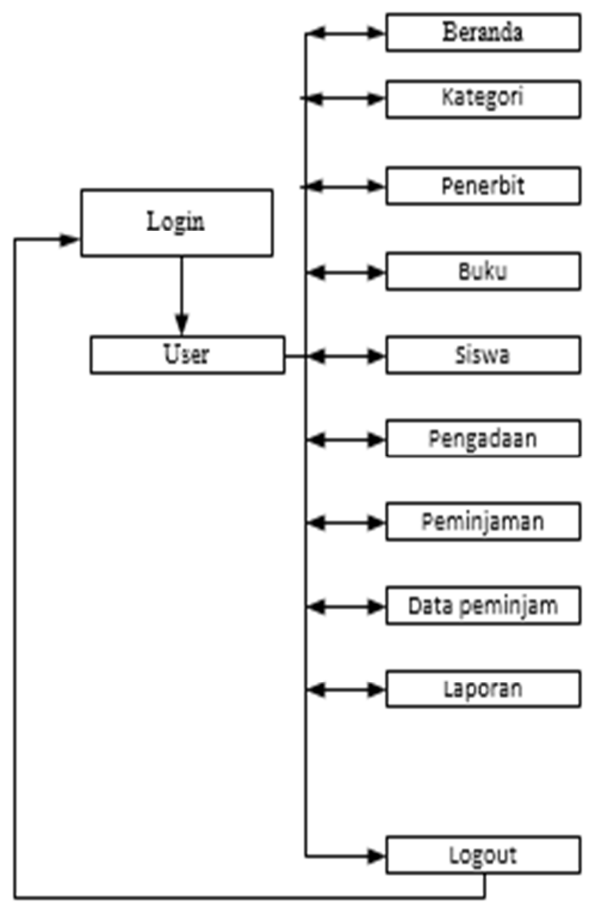

Gambar 7. Struktur Navigasi Halaman Beranda User

Sumber: : Hasil Penelitian (2017) 
Jurnal Inkofar * Volume 1 No. 2, Desember 2017 * ISSN: 2615-3645 (Print) / 2581-2920 (Online)

Tersedia secara online di: http://www.politeknikmeta.ac.id/meta/ojs/

\subsection{Implementasi dan Pengujian Unit}

3.4.1 Implementasi Rancangan Antar Muka

1. Implementasi Halaman Login Admin dan User

Untuk dapat masuk kedalam halaman utama admin pengguna harus memasukan username dan password dengan benar.

\section{SIMPUS SMKN 2 Kota Bekasi}

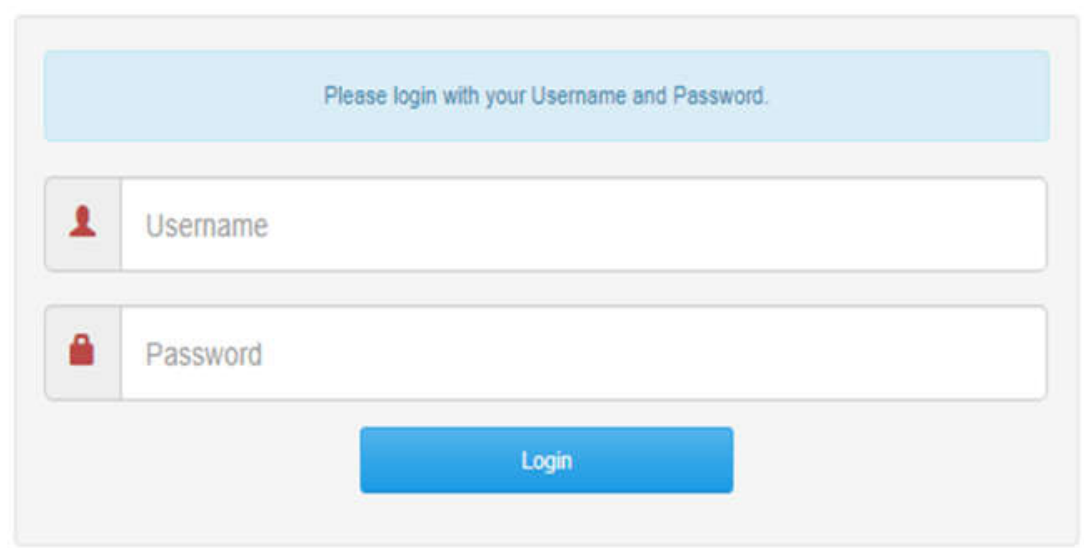

Gambar 8. Implementasi Halaman Login Admin dan User

Sumber: : Hasil Penelitian (2017)

2. Implementasi Halaman Beranda Admin

Beranda akses ruang lingkup admin yaitu meliputi form user, form modul, form kategori, form penerbit, form siswa, form peminjam, form data peminjam, laporan, identitas web dan logout.

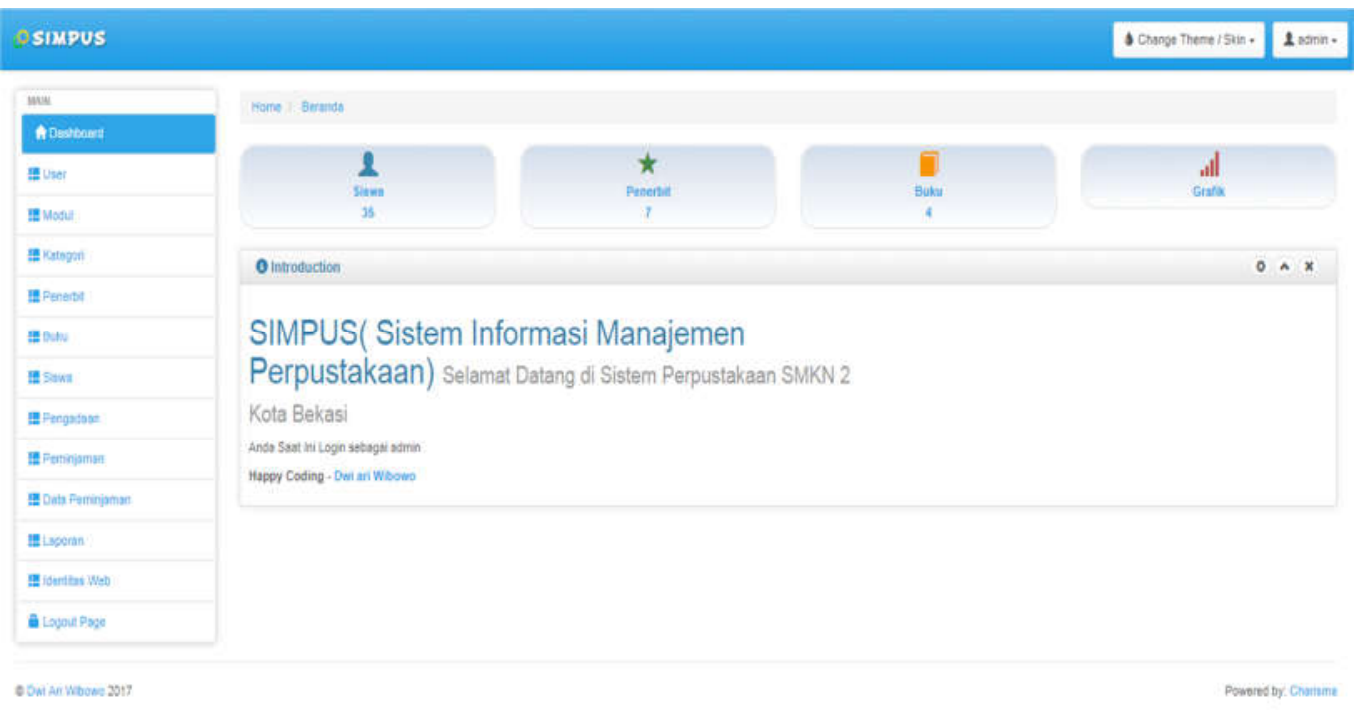

Gambar 9. Implementasi Halaman Beranda Admin

Sumber: : Hasil Penelitian (2017) 
Jurnal Inkofar * Volume 1 No. 2, Desember 2017 * ISSN: 2615-3645 (Print) / 2581-2920 (Online)

Tersedia secara online di: http://www.politeknikmeta.ac.id/meta/ojs/

3. Implementasi Halaman Transaksi Peminjaman Buku Baru

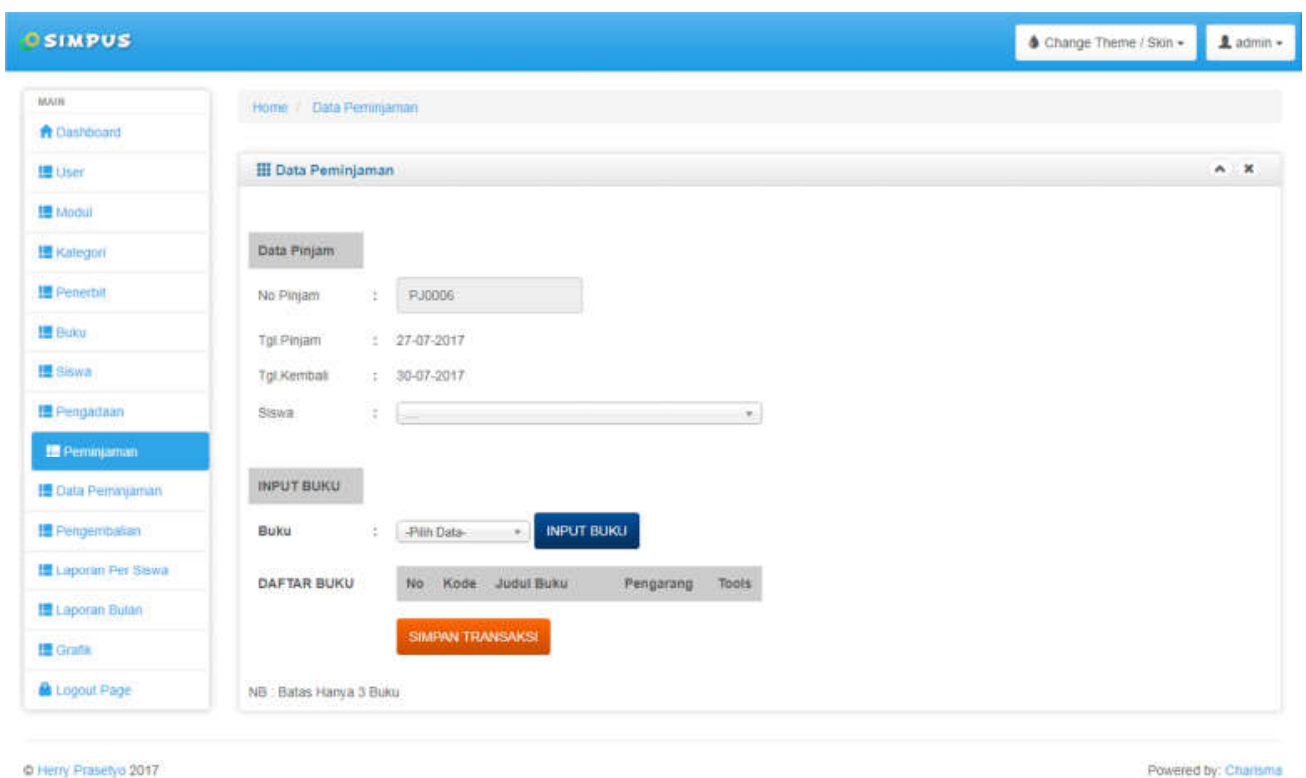

Gambar 10. Implementasi Halaman Transaksi Peminjaman Buku Baru Sumber: : Hasil Penelitian (2017)

\subsubsection{Pengujian Unit}

Tabel 1.Pengujian Black Box Testing Tambah Data Peminjam

Sumber: : Hasil Penelitian (2017)

\begin{tabular}{|c|c|c|c|c|c|}
\hline No. & $\begin{array}{c}\text { Skenario } \\
\text { Pengujian }\end{array}$ & Test Case & $\begin{array}{c}\text { Hasil yang } \\
\text { diharapkan }\end{array}$ & $\begin{array}{c}\text { Hasil } \\
\text { Pengujian }\end{array}$ & Kesimpulan \\
\hline 1 & $\begin{array}{l}\text { Mengosong } \\
\text { kansemua } \\
\text { isi data } \\
\text { tambah } \\
\text { peminjam, } \\
\text { lalu klik } \\
\text { tombol "Simpan". }\end{array}$ & $\begin{array}{l}\text { No } \\
\text { peminjaman: } \\
\text { Terisi } \\
\text { otomatis dan } \\
\text { tidak dapat } \\
\text { dihapus } \\
\text { Tanggal } \\
\text { peminjam: } \\
\text { Sudah } \\
\text { ditentukan } \\
\text { sistem } \\
\text { Tanggal } \\
\text { kembali: } \\
\text { Sudah } \\
\text { ditentukan } \\
\text { sistem } \\
\text { siswa: } \\
\text { (Kosong) } \\
\text { buku: } \\
\text { (Kosong) }\end{array}$ & $\begin{array}{l}\text { Sistem akan } \\
\text { menolak dan } \\
\text { menampilkan } \\
\text { pesan "anda } \\
\text { belum memilih } \\
\text { siswa" }\end{array}$ & $\begin{array}{l}\text { Sesuai } \\
\text { Harapan }\end{array}$ & Valid \\
\hline 2 & $\begin{array}{l}\text { Mengisi } \\
\text { data siswa, } \\
\text { dan } \\
\text { mengosongk } \\
\text { an data buku }\end{array}$ & $\begin{array}{l}\text { No } \\
\text { peminjaman: } \\
\text { Terisi } \\
\text { otomatis dan } \\
\text { tidak dapat }\end{array}$ & $\begin{array}{l}\text { Sistem akan } \\
\text { menolak dan } \\
\text { menampilkan } \\
\text { pesan "anda } \\
\text { belum memilih }\end{array}$ & Sesuai & Valid \\
\hline
\end{tabular}




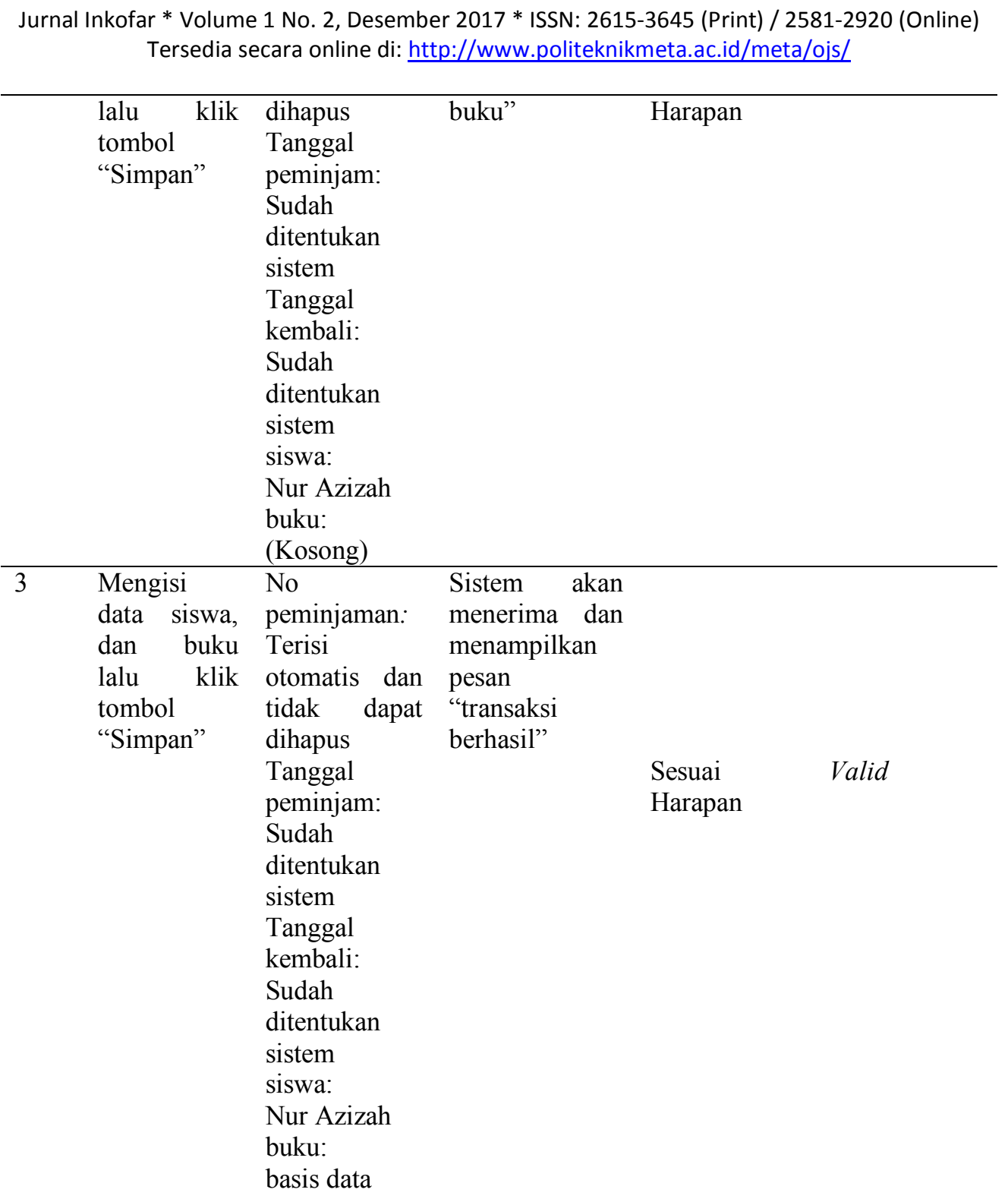

\section{KESIMPULAN}

Setelah dilakukan pengujian dan testing program, sistem yang terdapat didalam web Sistem Informasi Perpustakaan pada SMK Negeri 2 Kota Bekasi dapat berjalan dengan baik. Dengan menggunakan sarana sistem yang terkomputerisasi, sistem informasi perpustakaan dapat berjalan dengan mudah dan mempercepat dalam melakukan proses administrasi, baik peminjaman buku, pengembalian buku serta data data yang lain pada SMK Negeri 2 Kota Bekasi

\section{DAFTAR PUSTAKA}

Abdulloh, Rohi. 2016. Amazing Project Aplikasi Ujian Online Full Ajax. Cirebon: CV ASFA Solution.

Anhar. 2010. Panduan Menguasai PHP \& MySQL Secara Otodidak. Jakarta Selatan : Media Kita.

Ardhana, YM Kusuma. 2012. Dengan PHP: Membuat Website 30 Juta Rupiah. Jasakom.

Aryanto, Ernanda Yota Kadek dan Mahedy, Surya Kadek. 2014. Jaringan Komputer. Yogyakarta: Graha Ilmu.

Binanto, Iwan. 2010. Multimedia Digital - Dasar Teori dan Pengembangannya. Yogyakarta : CV. Andi Offset.

Irawan. 2011. Panduan Berinternet Untuk Orang Awam. Palembang : Maxikom.

Kadir, Abdul. 2013. Pemograman Database MySQL Untuk Pemula. Yogyakarta : Mediakom. 
Kadir, Abdul. 2015. Web Master Series: Javascript. Yogyakarta : Mediakom.

Munif, Abdul. 2013. Basis Data 1. Malang : Kementrian Pendidikan \& Kebudayaan.

Prasetio, Adhi. 2014. Buku Sakti Web Master. Jakarta Selatan : Mediakita.

Purnomo, Wahyu. 2013. Pemograman Web 1. Malang : Kementrian Pendidikan \& Kebudayaan.

Sadeli, Muhammad. 2014. Aplikasi Bisnis dengan PHP \& MySQL. Palembang : Maxikom.

Sidik, Betha., dan Husni Isakandar Pohan. 2014. Pemrograman Web dengan HTML. Bandung : Informatika Bandung.

Siyamta. 2013. Administrasi Server. Malang : Kementrian Pendidikan \& Kebudayaan.

Subrata, Gatot. 2009. Perpustakaan Digital. Diambil dari: http://library.um.ac.id/index.php/artikelpustakawan/mklgto7.html. (12 Mei 2017)

Sukamto Rosa, A., dan M. Shalahuddin. 2014. Rekayasa Perangkat Lunak (Terstruktur dan Berorientasi Objek). Bandung : Informatika Bandung.

Sulianta, Feri \& Umbara, Fajri Rakhmat. 2015. Teknik Hebat Merancang Aplikasi Instan dan Berkualitas. Jakarta: PT Elex Media Komputindo.

Utami, Ema., dan Anggit Dwi Hartanto. 2012. Sistem Basis Data Menggunakan Microsoft SQL Server 2005. Yogyakarta : CV. Andi Offset.

Zaki, Ali. 2014. Seri Penuntasan Praktis Ajax Untuk Pemula. Semarang : Smitdev community 